\title{
Plant protection costs in selected farms in Wielkopolskie Voivodeship
}

\author{
Koszty ochrony roślin w wybranych gospodarstwach rolnych \\ województwa wielkopolskiego
}

\author{
Jolanta Bojarszczuk*, Janusz Podleśny
}

\section{Summary}

The aim of the conducted study was an evaluation of plant protection products consumption and the cost-effectiveness of their usage in the selected farms in Wielkopolskie Voivodeship. The source material was the results of questionnaire surveys carried out in 2017. The study included farms with an arable land (AL) of over 10 ha. Due to analytical purposes the farms were divided into five groups (I-V) depending on the area of arable land: 10-20, 21-30, 31-50, 51-100 and above 100 ha. The amount of chemical plant protection was varied and depended on the farm size and crop species. The highest consumption of plant protection products, expressed in $\mathrm{kg}$ of active substance (a.s.) per area unit, characterised winter wheat cultivation ( $2.34 \mathrm{~kg}$ of a.s./ha), corn and mixed wheat was lower by 12 and $13 \%$ (respectively 2.06 and $2.03 \mathrm{~kg}$ of a.s./ha), and the lowest was cultivation of winter triticale and spring barley (respectively 1.91 and $1.75 \mathrm{~kg}$ of a.s./ha). The cultivation of the analysed species had the highest consumption of herbicides, much smaller of fungicides and the smallest of insecticides. The most favourable value of the cost coverage index was obtained in spring barley cultivation in farms with 21-30 ha of arable land (12.9) and corn cultivation in farms with arable land of 31-50 ha (12.9). The highest yield to cover the costs of chemical protection was allocated to the cultivation of winter triticale (average 11.5\%), the lowest in the cultivation of winter wheat (8.6\%).

Key words: farm, protection costs, profitability of production, cost coverage index, treatment profitability index, Wielkopolskie Voivodeship

\section{Streszczenie}

Celem badań była ocena zużycia środków ochrony roślin oraz kosztów i opłacalności ich zastosowania w uprawie wybranych gatunków roślin uprawianych w gospodarstwach województwa wielkopolskiego. Materiał źródłowy stanowiły wyniki badań ankietowych przeprowadzonych w 2017 roku. Uwzględniono typowo rolnicze gospodarstwa o powierzchni powyżej 10 ha użytków rolnych. Do celów analitycznych dokonano podziału gospodarstw na pięć grup (I-V) różniących się powierzchnią użytków rolnych (UR): 10-20, 21-30, 31-50, 51-100, powyżej 100 ha. Nakłady na chemiczną ochronę roślin były zróżnicowane w zależności od wielkości gospodarstwa i gatunku rośliny uprawnej. Największym zużyciem środków ochrony roślin wyrażonym w kg substancji czynnej w odniesieniu do jednostki powierzchni charakteryzowała się uprawa pszenicy ozimej (średnio 2,34 kg s.cz./ha), mniejszym o 12 i 13\% uprawa kukurydzy i mieszanki zbożowej (odpowiednio: 2,06 i 2,03 kg s.cz./ha), a najmniejszym uprawa pszenżyta ozimego i jęczmienia jarego (odpowiednio 1,91 i 1,75 kg s.cz./ha). W uprawie analizowanych gatunków stwierdzono największe zużycie herbicydów, znacznie mniejsze fungicydów i najmniejsze insektycydów. Najkorzystniejszą wartość wskaźnika pokrycia kosztów uzyskano w uprawie jęczmienia w gospodarstwach o powierzchni 21-30 ha UR $(12,9)$ oraz w uprawie kukurydzy w gospodarstwach o powierzchni 31-50 ha UR $(12,9)$. Najwięcej plonu na pokrycie kosztów zabiegów ochrony przeznaczano w uprawie pszenżyta ozimego (średnio 11,5\%), a najmniej w uprawie pszenicy ozimej (8,6\%).

Słowa kluczowe: gospodarstwo rolne, koszty ochrony, opłacalność uprawy, wskaźnik pokrycia kosztów, wskaźnik opłacalności zabiegów, województwo wielkopolskie

Instytut Uprawy Nawożenia i Gleboznawstwa - Państwowy Instytut Badawczy

Czartoryskich 8, 24-100 Puławy

*corresponding author: jbojarszczuk@iung.pulawy.pl

ORCID: 0000-0003-2065-344X 


\section{Wstęp / Introduction}

Zakres stosowania ochrony roślin jest uwarunkowany możliwościami ekonomicznymi, intensywnością organizacji produkcji i wielkością gospodarstwa (Bojarszczuk i Podleśny 2017). Nasilenie występowania agrofagów i konieczność ich zwalczania zależy również od gatunku rośliny uprawnej (Małecka-Jankowiak i wsp. 2015). Wynika z tego, że wielkość gospodarstwa i gatunek uprawianej rośliny mogą być czynnikami wpływającymi na koszty prowadzonej ochrony chemicznej. W 2017 roku, który był rokiem badań, sprzedaż środków ochrony roślin w Polsce wynosiła ogółem 25,1 tys. t substancji czynnych (s.cz.), w tym 1,8 tys. t s.cz. środków owadobójczych, 13,7 tys. $t$ s.cz. środków chwastobójczych, 2,1 tys. t s.cz. regulatorów wzrostu, 7,2 tys. t s.cz. środków grzybobójczych i zapraw nasiennych oraz 0,25 tys. t pozostałych s.cz. (GUS 2018; Analizy rynkowe 2019).

Zapobieganie powstającym stratom plonu jest możliwe przez zastosowanie ochrony uwzględniającej metody agrotechniczne oraz niezbędne zabiegi chemiczne (Pruszyński i Skrzypczak 2007). W obecnych technologiach rolniczych stosowanie chemicznych zabiegów ochrony roślin jest niezbędne, aby zabezpieczyć odpowiednią wielkość i jakość plonu (Golinowska 2009). Istotnym elementem produkcji roślinnej jest także bieżąca analiza efektów ekonomicznych uzyskiwanych na skutek wykonywanych zabiegów zwalczania agrofagów i poziomu uzyskiwanych plonów.

Celem badań była ocena zużycia chemicznych środków ochrony roślin i koszty ochrony chemicznej w wybranych gospodarstwach rolnych województwa wielkopolskiego w zależności od gatunku rośliny uprawnej i wielkości powierzchni.

\section{Materiały i metody / Materials and methods}

Źródło danych do przygotowania opracowania z zakresu prowadzonej ochrony chemicznej oraz jej kosztów stanowiły badania ankietowe przeprowadzone w gospodarstwach usytuowanych w różnych rejonach województwa wielkopolskiego (rys. 1). Dane niezbędne do przeprowadzenia analizy pochodzą z 2017 roku. Wyboru gospodarstw dokonano w sposób celowy, przy współpracy z Wielkopolskim Ośrodkiem Doradztwa Rolniczego (WODR) w Poznaniu. Pozyskane dane były weryfikowane przez gospodarstwa, WODR oraz Instytut Uprawy Nawożenia i Gleboznawstwa - Państwowy Instytut Badawczy w Puławach. Każda ankieta zawierała pytania dotyczące danych ogólnych o gospodarstwie, struktury zasiewów, wyposażenia w maszyny i urządzenia oraz szczegółowych danych o technologii produkcji roślinnej, a zwłaszcza o stosowanej ochronie roślin. W badaniach uwzględniono typowo rolnicze gospodarstwa o powierzchni powyżej 10 ha użytków rolnych(UR).

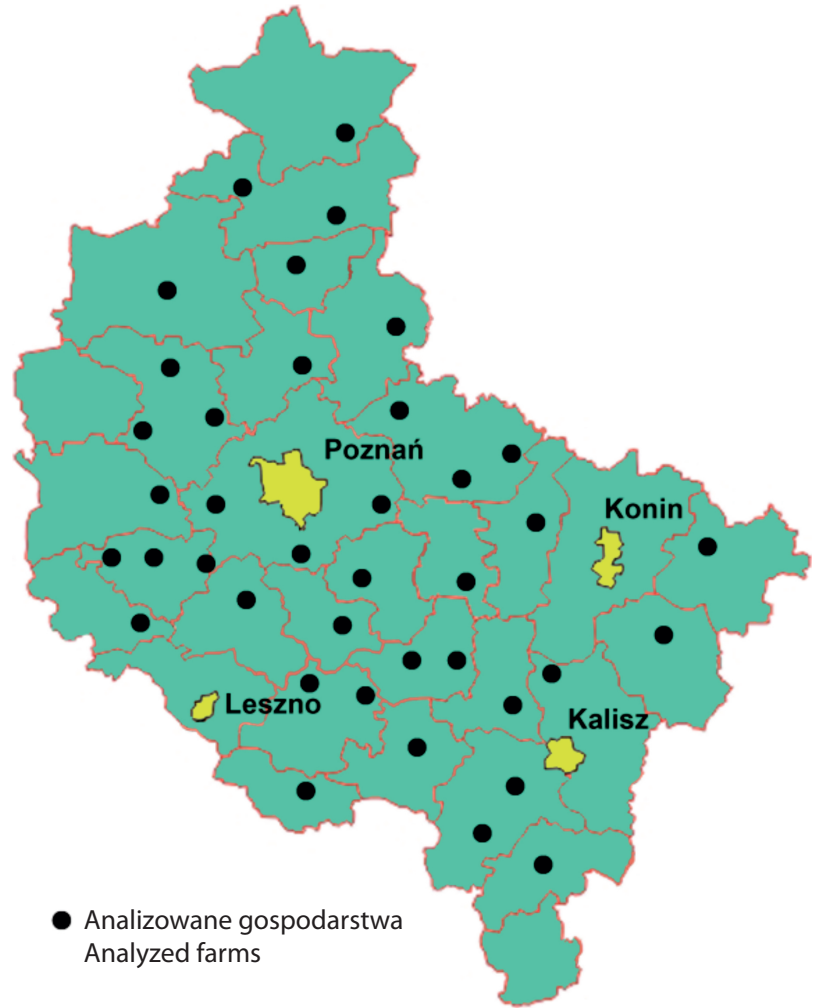

Rys. 1. Położenie badanych gospodarstw w województwie wielkopolskim

Fig. 1. Location of analyzed farms in Wielkopolskie Voivodeship

Do celów analitycznych dokonano podziału gospodarstw na pięć grup (I-V) różniących się powierzchnią UR: 10-20, 21-30, 31-50, 51-100 i powyżej 100 ha. Badania wykonano w 39 gospodarstwach (w grupie I - 6, II - 6, III - 9, IV - 9, $\mathrm{V}-9$ gospodarstw). Do badań wybrano 5 gatunków roślin form jarych i ozimych: pszenicę ozimą, mieszankę zbożową, kukurydzę, pszenżyto ozime i jęczmień jary, najczęściej uprawianych w analizowanych gospodarstwach.

Rachunek kosztów ochrony roślin przeprowadzono w oparciu o następujące wskaźniki: ilość zużytej substancji czynnej (s.cz. w kg/ha) oraz faktycznie poniesione koszty zabiegów ochrony roślin (zł/ha) (Mierzejewska 1989; Golinowska 2002, 2009). Porównano koszty ochrony roślin w zależności od wielkości gospodarstwa, wyrażonej w powierzchni UR. W analizie ekonomicznej opłacalności chemicznego zwalczania chwastów, szkodników i chorób wyliczono następujące wskaźniki: wskaźnik pokrycia kosztów - Wpk (stosunek wartości produkcji uratowanego plonu do kosztów zabiegu), wskaźnik opłacalności zabiegów - $\mathrm{E}_{1}$ (liczba dt produktu chronionego równoważącego koszty zabiegów ochronnych), procentowy wskaźnik kosztów $-\mathrm{E}_{2}$ (procent plonu plantacji chronionej, który należy przeznaczyć na zrównoważenie kosztów zabiegów).

$$
\mathrm{E}_{1}=\mathrm{Kz} / \mathrm{C}
$$


gdzie:

$\mathrm{Kz}$ - koszty zabiegów ochrony roślin (zł/ha),

$\mathrm{C}$ - cena $1 \mathrm{dt}$ produktu chronionego (zt/dt),

$\mathrm{P}$ - plon produktu chronionego (dt/ha).

$$
\mathrm{E}_{2}=\mathrm{E}_{1} \times 100 / \mathrm{P}
$$

Do obliczenia wyżej wymienionych wskaźników uwzględniono średnie ceny ziarna wybranych do badań gatunków roślin i zastosowanych środków ochrony roślin, które uzyskano na podstawie informacji z punktów sprzedażowych w 2017 roku oraz opracowania Instytutu Ekonomiki Rolnictwa i Gospodarki Żywnościowej - Państwowego Instytutu Badawczego (Rynek środków produkcji dla rolnictwa 2018). Obliczono koszty wykonania zabiegów z udziałem wybranych środków ochrony roślin na powierzchni 1 ha. Koszt ten przyjęto na podstawie danych zamieszczonych na stronie WODR w Poznaniu (http://www.wodr. poznan.pl).

\section{Wyniki i dyskusja / Results and discussion}

Rolnictwo wybranego do badań regionu charakteryzuje się wysokim poziomem kultury rolnej oraz dużą intensywnością i znacznym zróżnicowaniem regionalnym warunków do prowadzenia produkcji. Występują tu bowiem duże obszary o sprzyjających rolnictwu warunkach klimatycznoglebowych oraz regiony problematyczne dla prowadzenia działalności rolniczej.
W badanych gospodarstwach rolnych nakłady na chemiczną ochronę roślin były zróżnicowane, o czym świadczą wielkość zużycia środków ochrony roślin (s.cz./ha UR) w uprawie poszczególnych gatunków oraz poniesione koszty (tab. 1-2). Z przeprowadzonej analizy wynika, że najwięcej substancji czynnej na 1 ha w ochronie chemicznej wszystkich gatunków roślin (pszenicy ozimej, mieszanki zbożowej, kukurydzy, pszenżyta ozimego i jęczmienia jarego) stosowano w gospodarstwach o powierzchni powyżej 100 ha (odpowiednio: 3,00; 2,63; 3,15; 2,54; 2,46 kg s.cz./ha), zaś najmniej w gospodarstwach do 20 ha $(1,93$; 1,$48 ; 1,60 ; 1,13 ; 1,39 \mathrm{~kg} \mathrm{s.cz./ha)} \mathrm{(tab.} \mathrm{1).} \mathrm{Według} \mathrm{danych}$ GUS (2018) w analizowanych gospodarstwach zużycie substancji czynnej na 1 ha było znacznie większe niź średnio w Polsce. Od 2007 roku, zgodnie z metodologią określoną w przepisach rozporządzenia (WE) Nr 1185/2009 z dnia 25 listopada 2009 r. (DUUE 2009) w sprawie statystyk dotyczących pestycydów, badanie zużycia środków ochrony roślin w Polsce realizowane jest przez Państwową Inspekcję Ochrony Roślin i Nasiennictwa we współpracy z Ministerstwem Rolnictwa i Rozwoju Wsi, Głównym Urzędem Statystycznym oraz Instytutem Ochrony Roślin - Państwowym Instytutem Badawczym. W 2016 roku wskaźnik zużycia środków ochrony roślin w $\mathrm{kg}$ substancji czynnej na 1 ha wynosił w uprawie pszenżyta ozimego $0,76 \mathrm{~kg}$; kukurydzy - 0,75 kg; buraka cukrowego - 2,67 kg; cebuli - 4,56 kg oraz gruszy - 6,08 kg (GUS 2018). Największym zużyciem środków ochrony roślin wyrażonym w kg substancji czynnej na 1 ha zasiewów charakteryzowała się uprawa pszenicy ozimej (średnio 2,34 kg s.cz./ha), mniejszym

Tabela 1. Nakłady na chemiczną ochronę roślin w analizowanych gospodarstwach

Table 1. Inputs on chemical plant protection in analyzed farms

\begin{tabular}{|c|c|c|c|c|c|c|}
\hline \multirow{2}{*}{$\begin{array}{l}\text { Wyszczególnienie } \\
\text { Specification }\end{array}$} & \multicolumn{5}{|c|}{$\begin{array}{l}\text { Grupa obszarowa gospodarstw } \\
\text { Area group of farms }\end{array}$} & \multirow{2}{*}{$\begin{array}{l}\text { Średnia } \\
\text { Mean }\end{array}$} \\
\hline & I & II & III & IV & V & \\
\hline \multicolumn{7}{|c|}{$\begin{array}{l}\text { Zużycie środków ochrony roślin w kg s.cz./ha } \\
\text { Plant protection products consumption }\end{array}$} \\
\hline Pszenica ozima - Winter wheat & 1,93 & 2,31 & 2,03 & 2,42 & 3,00 & 2,34 \\
\hline Mieszanka zbożowa - Cereal mixture & 1,48 & 2,41 & 2,15 & 1,46 & 2,63 & 2,03 \\
\hline Kukurydza - Maize & 1,60 & 1,97 & 1,83 & 1,73 & 3,15 & 2,06 \\
\hline Pszenżyto ozime - Winter triticale & 1,13 & 2,08 & 1,79 & 2,03 & 2,54 & 1,91 \\
\hline Jęczmień jary - Spring barley & 1,39 & 1,76 & 1,75 & 1,40 & 2,46 & 1,75 \\
\hline \multicolumn{7}{|c|}{$\begin{array}{l}\text { Koszt zużycia środków ochrony roślin w zł/ha } \\
\text { Cost of using of plant protection products }\end{array}$} \\
\hline Pszenica ozima - Winter wheat & 343,3 & 302,7 & 304,9 & 366,8 & 396,6 & 342,9 \\
\hline Mieszanka zbożowa - Cereal mixture & 242,2 & 261,3 & 303,4 & 232,4 & 372,9 & 282,4 \\
\hline Kukurydza - Maize & 442,2 & 418,6 & 282,9 & 410,2 & 440,7 & 398,9 \\
\hline Pszenżyto ozime - Winter triticale & 407,5 & 271,1 & 275,7 & 353,3 & 321,0 & 325,7 \\
\hline Jęczmień jary - Spring barley & 291,2 & 238,3 & 278,4 & 220,6 & 310,6 & 267,8 \\
\hline
\end{tabular}

Źródło: opracowanie własne - Source: own study 
Tabela 2. Ilościowa struktura zużycia środków ochrony roślin [\%]

Table 2. The quantity structure of consumption of plant protection products [\%]

\begin{tabular}{|c|c|c|c|c|c|c|}
\hline \multirow{2}{*}{$\begin{array}{l}\text { Wyszczególnienie } \\
\text { Specification }\end{array}$} & \multicolumn{5}{|c|}{$\begin{array}{l}\text { Grupa obszarowa gospodarstw } \\
\text { Area group of farms }\end{array}$} & \multirow{2}{*}{$\begin{array}{c}\text { Średnia } \\
\text { Mean }\end{array}$} \\
\hline & $\mathrm{I}$ & II & III & IV & $\mathrm{V}$ & \\
\hline \multicolumn{7}{|c|}{ Herbicydy - Herbicides } \\
\hline Pszenica ozima - Winter wheat & 41,9 & 26,7 & 52,4 & 46,2 & 46,6 & 42,8 \\
\hline Mieszanka zbożowa - Cereal mixture & 84,6 & 42,1 & 17,4 & 95,9 & 55,2 & 59,0 \\
\hline Kukurydza - Maize & 81,7 & 36,9 & 100,0 & 98,0 & 34,0 & 70,1 \\
\hline Pszenżyto ozime - Winter triticale & 84,2 & 28,3 & 18,6 & 12,7 & 62,5 & 41,3 \\
\hline Jęczmień jary - Spring barley & 43,2 & 29,4 & 23,1 & 72,7 & 41,0 & 41,9 \\
\hline \multicolumn{7}{|c|}{ Fungicydy - Fungicides } \\
\hline Pszenica ozima - Winter wheat & 33,5 & 66,7 & 44,2 & 46,2 & 43,4 & 46,8 \\
\hline Mieszanka zbożowa - Cereal mixture & 15,4 & 52,6 & 49,6 & 4,1 & 36,8 & 31,7 \\
\hline Kukurydza - Maize & 18,3 & 50,0 & 0 & 2,0 & 47,2 & 23,5 \\
\hline Pszenżyto ozime - Winter triticale & 14,6 & 65,2 & 81,5 & 79,4 & 25,0 & 53,4 \\
\hline Jęczmień jary - Spring barley & 32,5 & 55,9 & 53,9 & 27,3 & 27,3 & 39,4 \\
\hline \multicolumn{7}{|c|}{ Insektycydy - Insecticides } \\
\hline Pszenica ozima - Winter wheat & 24,6 & 6,7 & 3,32 & 7,7 & 10,1 & 10,5 \\
\hline Mieszanka zbożowa - Cereal mixture & 0 & 5,3 & 33,1 & 0 & 8,1 & 9,3 \\
\hline Kukurydza - Maize & 0 & 13,1 & 0 & 0 & 18,9 & 6,4 \\
\hline Pszenżyto ozime - Winter triticale & 1,2 & 6,5 & 0 & 7,9 & 12,5 & 5,6 \\
\hline Jęczmień jary - Spring barley & 24,3 & 14,7 & 23,1 & 0 & 31,7 & 18,8 \\
\hline
\end{tabular}

Źródło: opracowanie własne - Source: own study

o 12 i 13\% uprawa kukurydzy i mieszanki zbożowej (odpowiednio 2,06 i 2,03 kg s.cz./ha), a najmniejszym uprawa pszenżyta ozimego i jęczmienia jarego (odpowiednio: 1,91 i $1,75 \mathrm{~kg}$ s.cz./ha) (tab. 1). Badania przeprowadzone przez Podleśnego i Podleśną (2018) w gospodarstwach rolnych w województwie dolnośląskim dowiodły, że spośród uprawianych gatunków zbóż najbardziej intensywną ochronę chemiczną stosowano w uprawie pszenicy ozimej (1,2 kg s.cz./ha). W Polsce w 2017 roku zużycie substancji czynnej zwiększyło się o 9\% w stosunku do 2013 roku (Analizy rynkowe 2019).

Stwierdzono znaczne różnice między grupami gospodarstw w zakresie poziomu ochrony chemicznej badanych gatunków roślin. Największe zużycie środków ochrony roślin w uprawie wszystkich analizowanych gatunków zanotowano w gospodarstwach o powierzchni powyżej 100 ha użytków rolnych. Natomiast najmniejsze w gospodarstwach o powierzchni do 20 ha (tab. 1). Jednocześnie w tych gospodarstwach wielkość nakładów w uprawie pszenicy ozimej, mierzona ilością substancji czynnej na 1 ha była o około $20 \%$ mniejsza niż w gospodarstwach w grupie III (31-50 ha UR). W odniesieniu do pozostałych gatunków roślin, relacje kształtowały się następująco: dla mieszanki zbożowej (-22\%), dla kukurydzy (-49\%), pszenżyta ozimego $(-56 \%)$ i jęczmienia jarego $(-44 \%)$.
Podleśny i Podleśna (2018) dowiedli, że w gospodarstwach o powierzchni powyżej 30 ha, zużycie substancji czynnej w uprawie pszenicy było o około $26 \%$ większe niż w pozostałych grupach gospodarstw. Jankowiak i wsp. (2012) również wykazali, że intensywność ochrony chemicznej zależy od struktury obszarowej gospodarstw.

Potwierdzają to badania Golinowskiej (2005) przeprowadzone w wielkoobszarowych gospodarstwach Dolnego Śląska, które dowiodły, że zużycie pestycydów w uprawie pszenicy wahało się od 2,0 do 4,8 kg, w uprawie jęczmienia było znacznie niższe niż w pszenicy i wynosiło od 0,3 do $1,0 \mathrm{~kg}$, zaś w uprawie kukurydzy kształtowało się na poziomie od 1,4 do 2,1 kg s.cz. na 1 ha.

Badania Noworolnika i Leszczyńskiej (2011) dowodzą, że zastosowanie właściwej ochrony zbóż, odpowiednie dobranie terminu zabiegu, a także użycie skutecznych insektycydów i fungicydów pozwala zapewnić znaczną zwyżkę plonu oraz poprawę parametrów i zdrowotności ziarna. Ponadto badania Noworolnika (2012) wskazują, że stosowanie tylko samych fungicydów w uprawie jęczmienia jarego wpłynęło na wzrost plonu ziarna ograniczając porażenie przez występujące patogeny chorobotwórcze.

Koszty ponoszone na ochronę roślin były zróżnicowane $\mathrm{w}$ zależności od gatunku rośliny i wielkości gospodarstwa. Najwyższe łączne koszty na ochronę roślin ponoszono 
w uprawie kukurydzy (średnio 400 zł/ha). Wysoki poziom kosztów ponoszonych na ochronę tego gatunku (średnio 497 zł/ha) potwierdzają wcześniejsze badania autorów przeprowadzone w 2016 roku w województwie lubelskim (Bojarszczuk i Podleśny 2017). Również Golinowska (2005) podkreśla wysoki poziom wskaźnika kosztochłonności ochrony chemicznej kukurydzy w stosunku do innych gatunków roślin. Nieco niższe łączne koszty ochrony chemicznej ponoszono w uprawie pszenicy ozimej (343 zł/ha), natomiast najniższe w uprawie pszenżyta ozimego (268 zł/ha), mieszanki zbożowej (282 zł/ha) i jęczmienia jarego (268 zł/ha) (tab. 1).

Największe nakłady na zużycie środków ochrony roślin, wyrażone zarówno kosztami zakupu środków ochrony roślin, jak i ich zastosowania, ponoszono w gospodarstwach większych obszarowo w grupie IV i V, a najmniejsze w gospodarstwach w grupie I i II. Wynika to z faktu, że w gospodarstwach najmniejszych stosowano mniej intensywną ochronę chemiczną, niż w gospodarstwach większych. Na tej podstawie można stwierdzić, że rośliny uprawiane w gospodarstwach wielkoobszarowych były chronione bardziej intensywnie. Podobne zależności stwierdziła Golinowska (2005) we wcześniej przeprowadzonych badaniach w województwie dolnośląskim.
Struktura zużycia środków ochrony roślin w procesie produkcji ziemiopłodów była zróżnicowana. Stosowano najwięcej herbicydów, znacznie mniej fungicydów, a najmniej insektycydów (tab. 2). Również z badań Golinowskiej i wsp. (2014) wynika, że w produkcji roślinnej stosowanie herbicydów i fungicydów jest bardziej powszechne niż insektycydów. Największe zużycie herbicydów zanotowano w uprawie kukurydzy (70\%) oraz mieszanki zbożowej (59\%), zaś najmniejsze w uprawie pszenżyta i jęczmienia $(42 \%)$. Najwięcej fungicydów stosowano w uprawie ozimych form zbóż: pszenżyta (53\%) i pszenicy (47\%). Natomiast największy udział insektycydów zanotowano w uprawie jęczmienia (19\%).

Przeprowadzona analiza stosowania poszczególnych grup środków ochrony roślin w zależności od wielkości gospodarstwa dowiodła, że najwięcej herbicydów i fungicydów stosowano w gospodarstwach o powierzchni: 31-50 i 51-100 ha (grupy III i IV), natomiast insektycydów w gospodarstwach o powierzchni powyżej 100 ha (grupa V) (tab. 2).

Efekty ekonomiczne stosowania pestycydów w uprawie badanych gatunków roślin przedstawiono w tabeli 3 . Wskaźnik pokrycia kosztów był wysoki i wynosił średnio dla wszystkich gospodarstw od 9,0 w uprawie pszenży-

Tabela 3. Wskaźniki charakteryzujące koszty i opłacalność zabiegów ochrony roślin

Table 3. Index characterized of cost and profitability of protective treatments

\begin{tabular}{|c|c|c|c|c|c|c|}
\hline \multirow{2}{*}{$\begin{array}{l}\text { Wyszczególnienie } \\
\text { Specification }\end{array}$} & \multicolumn{5}{|c|}{$\begin{array}{l}\text { Grupa obszarowa gospodarstw } \\
\text { Area group of farms }\end{array}$} & \multirow{2}{*}{$\begin{array}{c}\text { Średnia } \\
\text { Mean }\end{array}$} \\
\hline & I & II & III & IV & $\mathrm{V}$ & \\
\hline \multicolumn{7}{|c|}{$\begin{array}{l}\text { Wskaźnik pokrycia kosztów (Wpk) } \\
\text { Cost covering ratio }\end{array}$} \\
\hline Pszenica ozima - Winter wheat & 9,72 & 13,01 & 14,01 & 11,83 & 10,94 & 11,90 \\
\hline Mieszanka zbożowa - Cereal mixture & 9,34 & 10,65 & 8,60 & 9,98 & 7,78 & 9,27 \\
\hline Kukurydza - Maize & 7,16 & 11,43 & 12,93 & 11,32 & 11,02 & 10,77 \\
\hline Pszenżyto ozime - Winter triticale & 7,59 & 11,87 & 8,98 & 7,00 & 9,64 & 9,02 \\
\hline Jęczmień jary - Spring barley & 10,60 & 12,87 & 7,73 & 11,20 & 9,94 & 10,47 \\
\hline \multicolumn{7}{|c|}{$\begin{array}{c}\text { Wskaźnik opłacalności zabiegów }\left(\mathrm{E}_{1}\right)[\mathrm{dt}] \\
\text { Index of treatment profitability }[\mathrm{dt}]\end{array}$} \\
\hline Pszenica ozima - Winter wheat & 5,14 & 4,54 & 4,57 & 5,50 & 5,94 & 5,14 \\
\hline Mieszanka zbożowa - Cereal mixture & 4,18 & 4,51 & 5,23 & 4,01 & 6,43 & 4,87 \\
\hline Kukurydza - Maize & 6,28 & 5,95 & 4,02 & 5,83 & 6,26 & 5,67 \\
\hline Pszenżyto ozime - Winter triticale & 6,59 & 4,38 & 4,46 & 5,71 & 5,19 & 5,27 \\
\hline Jęczmień jary - Spring barley & 4,72 & 3,86 & 6,60 & 3,57 & 5,03 & 4,76 \\
\hline \multicolumn{7}{|c|}{$\begin{array}{l}\% \text { zbioru na pokrycie kosztów ochrony }\left(\mathrm{E}_{2}\right) \\
\text { Share of harvest on cover of plant protection costs }\end{array}$} \\
\hline Pszenica ozima - Winter wheat & 10,30 & 7,69 & 7,14 & 8,46 & 9,14 & 8,55 \\
\hline Mieszanka zbożowa - Cereal mixture & 10,70 & 9,39 & 11,62 & 10,02 & 12,86 & 10,92 \\
\hline Kukurydza - Maize & 14,00 & 8,75 & 7,73 & 8,83 & 9,08 & 9,68 \\
\hline Pszenżyto ozime - Winter triticale & 13,20 & 8,43 & 11,14 & 14,28 & 10,38 & 11,49 \\
\hline Jęczmień jary - Spring barley & 9,43 & 8,04 & 12,94 & 8,93 & 10,06 & 9,88 \\
\hline
\end{tabular}

Źródło: opracowanie własne - Source: own study 
ta ozimego do 11,9 w uprawie pszenicy ozimej. Najkorzystniejszą wartość uzyskano w uprawie pszenicy ozimej i kukurydzy w gospodarstwach należących do III grupy obszarowej (odpowiednio: 14,0 i 12,9) oraz w uprawie jęczmienia jarego $\mathrm{w}$ gospodarstwach o powierzchni $21-30$ ha UR $(12,9)$. Najmniej korzystną wartość wskaźnika stwierdzono w uprawie pszenżyta ozimego w gospodarstwach o powierzchni 51-100 ha UR $(7,0)$ oraz w uprawie kukurydzy w najmniejszych gospodarstwach $(7,16)$. Uzyskane wyniki wskazują, że koszty poniesione na ochronę chemiczną badanych gatunków roślin zwróciły się w dużym stopniu. Zdaniem Kaniuczaka (2000, 2002a, b, 2015) wysokie wskaźniki opłacalności zabiegów w uprawie zbóż sygnalizują coraz mniej korzystną relację między kosztami ochrony a ceną zbytu ziarna.

Wskaźnik opłacalności ochrony roślin, określający część plonu jaką należy przeznaczyć na pokrycie kosztów wykonania zabiegu, był zróżnicowany w poszczególnych gospodarstwach i wynosił: w uprawie pszenicy ozimej od 4,54 do 5,94 dt; mieszanki zbożowej od 4,01 do $6,43 \mathrm{dt}$; kukurydzy od 4,02 do 6,28 dt; pszenżyta ozimego od 4,38 do 6,59 dt; zaś jęczmienia jarego od 3,57 do 6,60 dt ziarna (tab. 3). Najwyższy poziom wskaźnika, świadczący o najniższej opłacalności przeprowadzonych zabiegów zanotowano w uprawie kukurydzy. Koszty zabiegów ochronnych zostały zrównoważone wartością 5,67 dt ziarna kukurydzy. Poziom tego wskaźnika był zróżnicowany w zależności od powierzchni gospodarstwa. Najniższą opłacalność zastosowanych zabiegów ochrony roślin wyrażoną w dt w uprawie pszenicy ozimej oraz mieszanki zbożowej zanotowano dla gospodarstw o powierzchni powyżej 100 ha (grupa V), w uprawie pszenżyta jarego i kukurydzy w gospodarstwach do 20 ha (grupa I), zaś $\mathrm{w}$ uprawie jęczmienia jarego $\mathrm{w}$ gospodarstwach o powierzchni w zakresie 31-50 ha (grupa III).

Najwięcej plonu na pokrycie kosztów zabiegów ochrony przeznaczano w uprawie pszenżyta ozimego (średnio $11,5 \%)$, znacznie mniej w kukurydzy $(9,7 \%)$, zaś najmniej w uprawie pszenicy ozimej $(8,6 \%)$. Spośród analizowanych grup gospodarstw, największy \% zbio- ru na pokrycie kosztów ochrony roślin przeznaczano w gospodarstwach najmniejszych obszarowo. Na kształtowanie tego wskaźnika wpływ miało szereg czynników, takich jak: zastosowany preparat chemiczny i jego cena, wielokrotność zabiegu, cena zbytu i wielkość uzyskanego plonu.

\section{Wnioski / Conclusions}

1. Nakłady na chemiczną ochronę roślin były zróżnicowane i zależały od wielkości gospodarstwa i gatunku rośliny uprawnej.

2. Największym zużyciem środków ochrony roślin wyrażonym $\mathrm{w} \mathrm{kg}$ substancji czynnej $\mathrm{w}$ odniesieniu do jednostki powierzchni charakteryzowała się uprawa pszenicy ozimej (średnio 2,34 kg s.cz./ha), mniejszym uprawa kukurydzy i mieszanki zbożowej (odpowiednio: 2,06 i 2,03 kg s.cz./ha), a najmniejszym uprawa pszenżyta ozimego i jęczmienia jarego (odpowiednio 1,91 i 1,75 kg s.cz./ha).

3. Najkorzystniejszą wartość wskaźnika opłacalności zabiegów uzyskano w uprawie pszenicy ozimej i kukurydzy w gospodarstwach należących do III grupy obszarowej (31-50 ha) oraz w uprawie jęczmienia jarego w gospodarstwach o powierzchni 21-30 ha UR.

4. Najwięcej plonu na pokrycie kosztów zabiegów ochrony przeznaczano w uprawie pszenżyta ozimego (średnio $11,5 \%$ ), a najmniej w uprawie pszenicy ozimej $(8,6 \%)$.

\section{Podziękowanie / Acknowledgements}

Praca wykonana w ramach realizacji zadania 2.3 Programu Wieloletniego Instytutu Uprawy Nawożenia i Gleboznawstwa - Państwowego Instytutu Badawczego w Puławach pt. „Wspieranie działań w zakresie ochrony i racjonalnego wykorzystania rolniczej przestrzeni produkcyjnej w Polsce oraz kształtowania jakości surowców roślinnych na lata 2016-2020".

\section{Literatura / References}

Analizy rynkowe 2019. Rynek środków produkcji dla rolnictwa. Stan i perspektywy. Instytut Ekonomiki Rolnictwa i Gospodarki Żywnościowej - Państwowy Instytut Badawczy, Warszawa, 44 ss.

Bojarszczuk J., Podleśny J. 2017. Koszty ochrony roślin w wybranych gospodarstwach rolnych województwa lubelskiego. [Plant protection costs in the selected farms in Lublin Voivodeship]. Progress in Plant Protection 57 (4): 266-271. DOI: 10.14199/ppp-2017-041

DUUE 2009. Rozporządzenie Parlamentu Europejskiego i Rady (WE) Nr 1185/2009 z dnia 25 listopada 2009 r. w sprawie statystyk dotyczących pestycydów. Dziennik Urzędowy Unii Europejskiej: 1-22.

Golinowska M. 2002. Efektywność ochrony roślin w indywidualnych gospodarstwach rolnych południowo-zachodniej Polski. Zeszyty Naukowe Akademii Rolniczej we Wrocławiu 433, 199 ss.

Golinowska M. 2005. Koszty i opłacalność chemicznej ochrony zbóż w gospodarstwach wielkoobszarowych na początku XXI wieku. [The costs and profitability of the chemical cereal protection on big-area farms at the beginning of the 21 st century]. Roczniki Naukowe Stowarzyszenia Ekonomistów Rolnictwa i Agrobiznesu 7 (1): 42-46.

Golinowska M. 2009. Ekonomika ochrony roślin w teorii i praktyce. [Economics of plant protection in theory and practice]. Progress in Plant Protection/Postępy w Ochronie Roślin 49 (1): 23-33. 
Golinowska M., Wiciak T., Kruszyński M., Adamska H. 2014. Intensywność nakładów na chemiczną ochronę roślin w gospodarstwie indywidualnym. [Intensity of expenditure on chemical weed control in an individual farm]. Roczniki Naukowe Stowarzyszenia Ekonomistów Rolnictwa i Agrobiznesu 16 (1): 50-56.

GUS 2018. Rolnictwo w 2017 roku. Główny Urząd Statystyczny, Warszawa, 204 ss.

Jankowiak J., Bieńkowski J., Holka M., Dąbrowicz R. 2012. Zużycie środków ochrony roślin na tle zmian w produkcji rolniczej. [The consumption of plant protection products in the background of changes in agricultural production]. Progress in Plant Protection/Postępy w Ochronie Roślin 52 (4): 1177-1183. DOI: 10.14199/ppp-2012-202

Kaniuczak Z. 2000. Ocena ekonomicznej efektywności stosowania fungicydów w zbożach. Roczniki Akademii Rolniczej w Poznaniu 321, Ogrodnictwo 30: 49-54.

Kaniuczak Z. 2002a. Skuteczność niektórych fungicydów w zwalczaniu chorób powodowanych przez grzyby i ich wpływ na plon ziarna jęczmienia jarego. [Efficacy of some fungicides for control of fungi and their influence of seed yield in spring barley]. Acta Agrobotanica 55 (1): 119-126.

Kaniuczak Z. 2002b. Wpływ chemicznej ochrony przed szkodnikami na plonowanie jęczmienia jarego. [Influence of chemical protection against pests of the crops in spring barley]. Progress in Plant Protection 42 (2): 616-618.

Kaniuczak Z. 2015. Ocena ekonomiczna efektywności zwalczania wybranych chorób i szkodników w uprawie jęczmienia jarego. [Economic evaluation of effectiveness of the control of selected diseases and pests in cultivation of spring barley]. Progress in Plant Protection 55 (4): 409-416. DOI: 10.14199/ppp-2015-069

Małecka-Jankowiak I., Blecharczyk A., Sawinska Z., Piechota T., Waniorek B. 2015. Wpływ następstwa roślin i systemu uprawy roli na zachwaszczenie pszenicy ozimej. [Impact of crop sequence and tillage system on weed infestation of winter wheat]. Fragmenta Agronomica 32 (3): 54-63.

Mierzejewska W. 1989. Rachunek kosztów w ochronie roślin. [Calculation of costs in the plant protection]. Zeszyty Problemowe Postępów Nauk Rolniczych 363: 9-21.

Noworolnik K. 2012. Wpływ fungicydów na plonowanie i jakość ziarna browarnych odmian jęczmienia. [Effect of fungicides on yielding and grain quality of malting barley cultivars]. Progress in Plant Protection/Postępy w Ochronie Roślin 52 (3): 642-645. DOI: 10.14199/ppp-2012-112

Noworolnik K., Leszczyńska D. 2011. Wpływ wybranych fungicydów na plonowanie kilku odmian jęczmienia jarego. [Effect of fungicides on grain quality of barley cultivar]. Progress in Plant Protection 51 (2): 668-671.

Podleśny J., Podleśna A. 2018. Ochrona roślin w gospodarstwach rolnych województwa dolnośląskiego. [Protection of plants in farms of Lower Silesia voivodeship]. Progress in Plant Protection 58 (4): 235-240. DOI: 10.14199/pp-2018-031

Pruszyński S., Skrzypczak G. 2007. Ochrona roślin w zrównoważonym rolnictwie. [Plant protection in sustainable agriculture]. Fragmenta Agronomica 4 (4): 127-138.

Rynek środków produkcji dla rolnictwa 2018. Nr 45/2018. Instytut Ekonomiki Rolnictwa i Gospodarki Żywnościowej - Państwowy Instytut Badawczy, Warszawa, 48 ss. ISSN 2081-8815.

Strona internetowa Wielkopolskiego Ośrodka Doradztwa Rolniczego w Poznaniu, http://www.wodr.poznan.pl [data dostępu: 24.03.2020]. 